\title{
Pengembangan Media ICT Berbasis Proyektor Interaktif Bagi Guru dan Siswa Raudhathul Athfal (RA)
}

\author{
Dindin Sobiruddin, Gelar Dwirahayu, Dedek Kustiawati \\ UIN Syarif Hidayatullah Jakarta
}

\section{Edcomtech}

\author{
Jurnal Kajian \\ Teknologi Pendidikan \\ Volume 4, No 1, April 2019 \\ 8-18
}

Submitted 01-14-2019

Accepted 03-20-2019

Corresponding Author

Dindin Sobirudin,

dindin.sobiruddin@uinjkt.ac.id

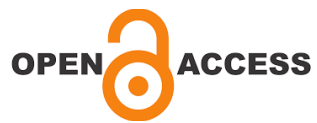

\begin{abstract}
Abstrak
Kecanggihan teknologi telah merambah pada berbagai aspek kehidupan, salah satu diantaranya adalah pemanfaat teknologi dalam bidang pendidikan di Tingkat RA. Penelitian ini terintegrasi dengan kegiatan pengabdian kepada masyarakat yang bertujuan untuk melatih guru-guru RA untuk 1) memanfaatkan media pembelajaran ICT berbasis proyektor interaktif dalam pembelajaran, 2) mengembangkan media ICT berbasis proyektor interaktif bagi anak usia dini, 3) memberikan gambaran tentang aktivitas siswa RA dalam pembelajaran yang menggunakan media ICT berbasis proyektor interaktif. Metode Metode R\&D digunakan dalam mengembangkan aplikasi dan media ICT berbasis proyektor interaktif dalam meningkatkan aktivitas belajar siswa RA di kelas. Uji coba media ICT berbasis proyekor interaktif dilakukan di dua RA yaitu siswa RA Al-Hidayah dan siswa RA Al-Husaeni. kabupaten Pandeglang Propinsi Banten. Hasil penelitian menunjukkan bahwa 1) tersusun aplikasi pembelajaran interaktif bagi anak usia dini yang menggunakan media ICT berbasis proyektor interaktif, 2) Proses pembelajaran tematik di RA yang menggunakan media media ICT berbasis proyektor interaktif sangat menyenangkan, hal ini ditunjukkan oleh antusias siswa dalam mengikuti pelajaran, dan juga terjadi peningkatan aktifitas belajar siswa RA di Kabupaten Pandeglang. 3) Guru memberikan respon yang positif terhadap penggunaan proyektor interaktif dalam pembelajaran tematik di kelas RA.
\end{abstract}

Kata Kunci: ICT berbasis proyektor interaktif, aplikasi pembelajaran, aktivitas siswa, raudhatul athfal (RA)

\begin{abstract}
Technological sophistication has penetrated various aspects of life, one of which is technology users in the field of education at the RA level. This research is integrated with community service activities that aim to train RA teachers to 1) utilize interactive projector-based ICT learning media in learning, 2) develop interactive projector-based ICT media for early childhood, 3) provide an overview of RA student activities in learning that uses interactive projector-based ICT media. The $R \& D$ Method method is used in developing interactive projector-based ICT applications and media in improving RAstudent learning activities in the classroom. An interactive projector-based ICT media trial was conducted in two RA namely RA Al-Hidayah students and RA Al-Husaeni students. Pandeglang district, Banten Province. The results showed that 1) arranged interactive learning applications for early childhood children using interactive projector-based ICT media, 2) Thematic learning process in RA that used interactive projector-based ICT media media was very pleasant, this was shown by the enthusiasm of students in attending lessons, and also increased learning activities of RAstudents in Pandeglang Regency. 3) The teacher gives a positive response to the use of interactive projectors in thematic learning in the RA class.
\end{abstract}

Keywords: ICT based inteactive projector, learning application, student activity, raudhatul athfal (RA) 


\section{LATAR BELAKANG}

Seiring dengan penggunaan teknologi dalam berbagai bidang, dan pemanfaatan teknologi dalam bidang pendidikan, maka kurikulum 2013 mengharuskan guru memanfaatkan teknologi dalam kegiatan pembelajaran, misalnya dalam administrasi pendidikan maupun pemanfaatannya dalam proses pembelajaran di kelas sebagai media yang mengantarkan siswa pada dunia nyata yang lebih ril dan lebih luas, dan tidak terbatas pada dinding kelas, oleh karena itu dengan memanfaatkan teknologi akan mengantarkan siswa pada proses berpikir tingkat tinggi atau yang dikenal dengan High Order Thinking. Dengan kata lain bahwa pembelajaran di dalam kelas perlu dilakukan upaya reformasi (Suryadi, 2007) dari proses pembelajaran yang konvensional atau pembelajaran yang hanya menggunakan alat peraga atau mungkin pembelajaran yang menggunakan metode ceramah menjadi pembelajaran yang berbasis ICT. Sistem pembelajaran konvensional menurut pandangan teori belajar modern atau teori belajar konstruktivisme, dianggap tidak mampu mengembangkan kecerdasan, dan kreativitas siswa secara optimal, sehingga pemahaman siswa terhadap materi yang telah diajarkan tidak maksimal, karena pengetahuan menjadi sebuah hafalan. Proses pembelajaran konvensional pada umunya identic dengan setting ruangan kelas yang kaku dan formal sehingga situasi dan kondisi belajar menjadi hening dan diharapkan dapat menciptakan konsentrasi belajar bagi siswa secara maksimal. Selain itu, belajar konvensional juga menjadikan guru dan buku pegangan siswa menjadi sumber utama dalam proses belajar mengajar (Suryadi, 2007), dan media papan tulis sebagai sarana utama dalam proses transfer of knowledge.

Sudah banyak pengembangan media yang digunakan dalam pembelajaran di dalam kelas, misalnya penggunaan SMS untuk membangun komunikasi antara siswa dengan siswa dan siswa dengan guru, guru dengan orang tua, sehingga mampu meningkatkan pemahaman siswa terhadap materi yang diajarkan (Ibrahim, 2011), penggunaan iPad bagi siswa preschool di Australia (Creszency,
2014). Ada juga pengembangan ICT dalam pelajaran fisika di sekolah menengah kejuruan (Siahaan, 2012) dan materi sain di SD (Mustika 2013; Hayumuti, 2016), pengembangan bahan ajar TIK yang berbasis proyek bagi siswa SMP (Aisyi, 2013). Akan tetapi belum banyak peneliti di Indonesia yang menerapkan pembelajaran berbasis ICT pada tingkat pendidikan anak usia dini.

Media proyektor sudah banyak digunakan, baik dalam bidang pendidikan maupun dalam bidang lainnya, hanya saja pemanfaatan proyektor pada umumnya digunakan dalam memperbesar tampilan layar sehingga informasi, baik dalam bentuk tulisan atau gambar menjadi lebih jelas.

Proyektor interaktif atau disebut juga dengan teknologi touchscreen. Touch diartikan sebagai melakukan aktifitas dengan menggunakan jari untuk mengoperasikan komputer atau teknologi lainnya, sehingga istilah touchscreen diartikan oleh Crescenzi (2014) sebagai teknologi yang dapat meciptakan interaksi antara di penyaji atau presenter dengan tampilan atau layarnya menggunakan sentuhan secara langsung dengan jari.

Pembelajaran dengan menggunakan teknologi touchscreen, memerlukan multimodal sensori sistem (Crescenzi, 2014), atau dengan kata lain bahwa proses pembelajaran tidak hanya melihat dan menyentuh layar, akan tetapi proses pembelajaran yang menghubungkan antara pengalaman siswa dalam melihat objek, mendengar informasi, kemampuan motoric khususnya menyentuh layar dan juga perilaku atau tindakan siswa. Sehingga penggunaan interaksi multimodal sensori sistem akan berpengaruh pada perkembangan dan persepsi anak terhadap dunia. Hal ini sejalan dengan hasil penelitian yang dilakukan oleh Gangliu (2017) bahwa proses pembelajaran yang memanfaatkan animasi virtual pada web site revolutioner memberikan dampak positif terhadap kemampuan berpikir anak, sehingga model pendidikan yang digunakan pun berubah sesuai dengan pemanfaat animasi virtual tersebut.

Berdasarkan pendapat Crescenzi, bahwa pembelajaran dengan menggunakan 
proyektor touchscreen mampu mengembangkan kemampuan berpikir anak serta kecerdasan anak, maka penulis tertarik untuk mengembangkan media ICT dalam pembelajaran yang berbasis proyektor interaktif.

Karena luasnya tingkat pendidikan yang ada di Indonesia, maka penelitian ini dibatasi pada tingkat taman kanak-kanak (TK) atau raudhatul athfal (RA). TK atau RA merupakan jenjang pendidikan informal sebelum tingkat pendidikan sekolah dasar. Meskipun TK/ RA merupakan pendidikan informal, akan tetapi kurikulum tetap menuntut adanya kreativitas guru dalam proses pembelajaran. Usia pendidikan di TK/RA biasanya berkisar antara 3 sampai 5 tahun. Usia ini merupakan masa keemasan bagi anak, artinya bahwa pada rentang usia ini, anak memiliki rasa ingin tahu yang besar terhadap apa yang mereka rasakan melalui panca indera mereka. Guru memiliki tanggung jawab dalam mendidik dan mengenalkan siswa tentang dunia luar sehingga pemahaman anak tentang "sesuatu" menjadi terarah dan bermakna.

Pendidikan TK/RA merupakan bagian dari pendidikan anak usia dini atau yang dikenal dengan PAUD. Pendidikan pada usia dini bukanlah pendidikan formal, dimana anak dijejali dengan materi secara formal sehingga kemampuan kognitifnya meningkat. Pendidikan pada usia dini memiliki tujuan yaitu membentuk anak Indonesia yang berkualitas, melalui proses tumbuh dan berkembang sesuai dengan tingkat perkembangannya sebagaimana dikemukakan oleh Piaget tentang teori perkembangan mental anak. Melalui pendidikan anak usia dini diharapkan siswa memiliki kesiapan yang optimal ketika memasuki pendidikan dasar. Seperti kita ketahui sekarang ini bahwa pendidikan sekolah dasar sudah memiliki kurikulum yang formal.

Pendidikan anak usia dini dititikberatkan pada pertumbuhan dan perkembangan fisik, kecerdasan, sosio emosional, bahasa dan komunikasi berdasarkan keunikan dan karakteristik anak melalui tahap-tahap perkembangan mentalnya. Perkembangan fisik yang dimaksud adalah sejauh mana kemampuan siswa dalam memanfaatkan fisiknya untuk melakukan gerakan motorik halus dan kasar. Misalnya motoric halus: menggambar, memegang pulpen, mewarnai dan sebagainya. Sedangkan motoric kasar. Misalnya melakukan gerakan melompat, berlari dan sebagainya. Perkembangan kecerdasan siswa pada anak usia dinitidakdilihat darikemampuan menyelesaikan soal atau permasalahan, akan tetapi ditinjau dari daya pikir, daya cipta kreativitas menari, membuat karya seni, kecerdasan emosi marah, senang, sedih, dan kecerdasan spiritual, berdoa, menghormati kedua orang tua.

Teknologi tidak dapat dipisahkan dalam kehidupan, semua kalangan menggunakan teknologi setiap saat, bahkan anak-anak sekarang sangat menikmati fasilitas yang ditawarkan teknologi seperti laptop, android, tablet. Kondisi seperti ini juga terjadi pada anak usia dini (dibawah lima tahun) mereka sudah terampil dalam mengoperasikan permainan-permainan atau menonton youtube, bermain games, melihat video atau foto-foto meskipun mereka belum belajar membaca maupun menulis.

Kecanggihan teknologi sudah merambah pada teknologi handphone, bahkan ada handphone yang memiliki spesifikasi sama dengan laptop atau bahkan lebih canggih dari komputer.

Ketergantungan anak-anak terhadap handphone/android diakibatkan karena ada daya tarik tersendiri yang ditawarkan handphone sehingga terjadi interaksi dengan anak. Layar touchscreen pada handphone memungkinkan anak merasa menjadi satu dengan handphone yang sedang dimainkannya. Jika permainannya berhasil maka anak semakin percaya diri. Crescenzi (2014) mengatakan bahwa sentuhan merupakan bentuk dasar dari interaksi anak-anak pada usia dini, dan merupakan bagian bentuk dari system sensor yang saling terhubung antara apa yang dilihat, apa yang di dengar, dan apa yang dilakukan. Dampak positif dari teknologi bagi anak, khususnya dalam dunia pendidikan, antara lain:

1. Teknologi yang tidak terbatas ruang dan waktu akan membantu siswa untuk lebih menambah wawasannya, tidak hanya 
terbatas belajar di dalam kelas

2. Dengan adanya teknologi anak mampu bersosialisasi dengan teman-temannya tanpa dibatasi waktu belajar, mereka bisa bertanya kapan saja

3. Dengan menggunakan teknologi, anakanak dapat mengakses sumber informasi yang lebih luas dan tidak terbatas dengan ilmu yang ada pada buku teks

4. Tampilan materi yang berbasis teknologi akan membangkitkan motivasi belajar bagi siswa karena materi disampaikan secara menarik dan mengasyikan

5. Dengan teknologi akan membantu perkembangan kreatifitas anak

6. Teknologi bukanlah pengetahuan, akan tetapi skills. Kemampuan penggunaan teknologi anak akan berkembang cepat karena siswa lebih sering menggunakan teknologi dari pada orang tua.

Teknologi banyak dimanfaatkan untuk proses pendidikan pada anak usia dini, pada umumnya anak-anak belajar menggambar, mewarnai, dan membaca. Pengaruh positif teknologi komputer untuk anak usia dini adalah menstimulasi perkembangan yang terjadi antara koordinasi mata dengan ketepatan gerak tangan.

Dengan menggunakan computer akan mengatasi keterbatasan ruang, waktu dan daya indra; maksudnya bahwa anak-anak dapat mengakses informasi kapan saja, dimana saja; bahkan dengan teknologi video call, kita bisa menghubungi keluarga atau kerabat dekat untuk saling memberi kabar berita. Dengan menggunakan teknologi akan mendorong anak untuk belajar secara verbalitas dalam kata-kata tertulis atau lisan belaka, misalnya anak-anak yang suka menonton you tube, mereka pada akhirnya mereka akan menirukan apa yang ditonton dalam kata-kata maupun dalam perilaku. Dengan menggunakan teknologi akan melahirkan suasana yang menyenangkan bagi anak; anak dapat menjadi lebih tekun dan terpicu untuk belajar berkonsentrasi, misalnya anak-anak yang suka bermain games, mereka mencari sendiri cara atau strategi untuk memenangkan suatu permainan, ada kepuasan dan rasa percaya diri anak ketika mereka menang dan ada rasa penasaran serta berjuang untuk menang ketika mereka kalah.

Pada umumnya, guru TK/RA sudah melaksanakan proses pembelajaran yang aktif, hanya saja melalui proses pembalajaran yang konvensional. Proses pembelajaran yang dilakukan sifatnya tugas, misalnya membagikan lembar kerja siswa yang memuat gambar atau huruf atau angka yang harus ditebalkan, dicontoh/ditiru, atau diwarnai oleh siswa. Untuk pelajaran bernyanyi atau olah raga cukup, guru memberikan contoh gerakan kemudian siswa diminta untuk mengikuti gerakan sambil berhitung. Proses pembelajaran seperti ini dirasakan kurang menyenangkan bagi anak, karena anak-anak suka dengan suasana yang menyenangkan. Untuk membantu proses pembelajaran di TK/RA maka perlu dikembangkan media pembelajaran berbasis ICT berbasis proyektor interaktif agak siswa secara aktif terlibat dalam pelajaran, mampu berkomunikasi dengan yang lain, suasana belajar pun menjadi lebih hidup.

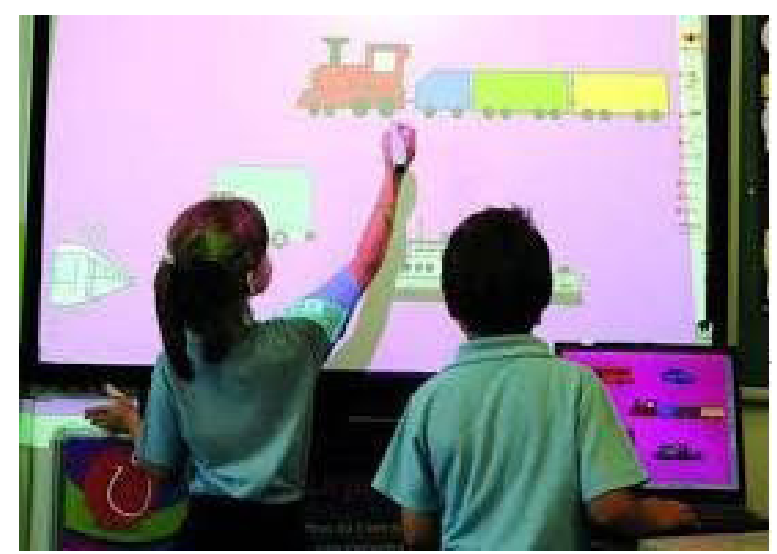

Gambar 1. Aktifitas Pembelajaran dengan Proyektor Interaktif

Gambar 1 menunjukkan aktivitas belajar yang menggunakan teknologi touchscreen melalui papan tulis, atau disebut dengan whiteboard interactive. Siswa diminta untuk menuliskan secara langsung di papan tulis, nama dan jenis alat transportasi. Berdasarkan uraian pada latar belakang masalah maka permasalahan dalam penelitian ini dibatasi pada: Pengembangan media pembelajaran tematik menggunakan media ICT berbasis proyektor interaktf, mengetahui respon guru tentang penggunaan proyektor interaktif dalam pembelajaran tematik di kelas RA dan 
efektivitas proses pembelajaran tematik di RA yang ada di wilayah kabupaten Pandeglang dengan menggunakan media ICT berbasis proyektor interaktif.

\section{METODE PENELITIAN}

Penelitian ini menggunakan metode Research and Development (R\&D), dimana penelitimengembangkanmediapembelajaran ICT berbasis proyektor interaktif bagi siswa RA. Research and Development (R\&D) sering diartikan sebagai suatu proses atau langkahlangkah untuk mengembangkan suatu produk baru atau menyempurnaan produk yang telah ada. langkah-langkah penelitian pengembangan ( $R$ \& $D$ ) dalam penelitian ini hanya meliputi lima tahap saja yaitu tahap pertama Penelitian dan Pengumpulan Data, tahap kedua Perencanaan, tahap ketiga Pengembangan Produk Awal, tahap ke empat Uji coba produk awal / Uji Coba Terbatas, dan tahap terakhir Penyempurnaan Produk Awal.

Penelitian dan Pengumpulan Data awal dilakukan melalui observasi awal ke beberapa RA da TK yang ada di wilayah Tangerang dan Jakarta khususnya untuk observasi kegiatan pembelajaran, kurikulum dan juga buku pegangan guru dan siswa. Selain itu dilakukan juga observasiawal ke pandeglang dan diperoleh data bahwa di wilayah pandeglang belum ada satupun sekolah RA yang menggunakan media ICT dalam pembelajaran, selanjutnya studi dokumentasi tentang pembelajaran tematik di tingkat pendidikan anak usia dini, dan kajian teori tentang pemafaatan ICT berbasis proyektor interaktif bagi pendidikan anak usia dini. Perencanaan, setelah mendapatkan data awal terkait dengan pelaksanaan pembelajaran pada anak usia dini, selanjutnya tim mendesain pembelajaran tematik untuk tingkat RA dan menyiapkan media ICT berbasis proyektor interaktif. Pengembangan Produk Awal dilakukan dengan menguji kelayakan media yang telah disusun dan dirangkaikan dengan aplikasi yang telah dibuat. Uji coba produk awal / Uji Coba Terbatas, uji coba dilaksanakan langsung di RA untuk mengetahui efektivitas media yang telah dibuat, dan tahap terakhir dalam penelitian ini adalah Penyempurnaan Produk Awal, hasil catatan dan observasi selama proses pembelajaran di RA menjadi landasan bagi peneliti dalam memperbaiki media dan juga aplikasi pembelajarannya. Teknik pengumpulan data dalam penelitian ini akan dilakukan dengan cara: dokumentasi dan penyebaran angket diberikan kepada guru.

\section{HASIL DAN PEMBAHASAN}

Sebagaimana tujuan penelitian yang telah ditetapkan yaitu mengembangkan media pembelajaran ICT berbasis proyektor interaktif bagi siswa anak usia dini (RA) maka langkah awal yang dilakukan oleh peneliti adalah merangkai media ICT.

Media ICT berbasis proyektor interaktif merupakan media pembelajaran yang telah dikembangkan oleh peneliti melalui pengalaman berkunjung ke salah satu taman kanak-kanak di Australia pada tahun 2009. Anak-anak sangat antusias melaksanakan pembelajaran, mereka senang belajar dengan menggunakan media whiteboard interaktif. Kondisi inilah yang mendorong peneliti untuk mengembangkan media pembelajaran ICT berbasis touchscreen. Setelah melakukan survey terhadap komponenkomponen penyusun media, maka peneliti mengembangkan media ICT berbasis proyektor interaktif dengan menggunakan panel touchscreen dengan alasan harga yang lebih terjangkau. Komponenkomponen untuk merangkai media ICT berbasis proyektor interaktif yang digunakan dalam penelitian ini terdiri dari:

\section{Android box}

Android Box adalah sebuah perangkat keras yang memiliki fungsi sebagai STB kepanjangan dari set top box. Dimana perangkatnya serupa dengan TV Box namun perangkat ini sudah tertanam OS (Operating System) Android, tetapi tidak dilengkapi dengan layar. Oleh karena itu dibutuhkan perangkat tambahan sebagai pengganti layar seperti LCD Proyektor yang dihubungkan dengan kabel HDMI. Android Box digunakan sebagai media penyimpanan data software pembelajaran, serta dilengkapi dengan wifi sehingga jika terhubung dengan internet, maka alat ini dapat mendownload secara langsung melaui web tanpa harus menggunakan USB lagi. 


\section{Panel touchscreen}

Panel touchscreen adalah sebuah perangkat, dimana inputnya adalah Android Box. Panel touchscreen bekerja dengan menggunakan sentuhan melalui tampilan layar pada panel dengan menggunakan jari atau pulpen digital. Melalui layar sentuh yang ditampilkan pada panel memungkinkan pengguna mengoperasikan Android Box dengan menyentuh gambar atau tulisan di layar itu sendiri.

Ukuran panel yang digunakan dalam penelitian yaitu 60", alasannya agar layar sentuh memiliki ukuran yang cukup lebar, sebab tempat pelatihan memiliki ruangan yang berukuran cukup luas dengan kapasitas peserta sebanyak 50 orang, sehingga gambar-gambar yang muncul menjadi jelas, jumlah guru peserta yang hadir sebanyak 56 orang sehingga memungkinkan mereka dapat melihat dengan jelas gambar yang ditampilkan pada layar, begitu pula dengan siswa-siswa RA dapat menggunakan media dengan jelas.

Teknologi proyektor interaktif dalam penelitian ini sering juga disebut juga dengan teknologi touchscreen atau teknologi layar sentuh. Hampir semua produk gadget sekarang ini dikemas dalam bentuk touchscreen dan bahkan komputer pun sudah ada beberapa yang menawarkan fasilitas touchscreen. Hal ini bertujuan untuk mempermudah penggunaannya. Penggunaan teknologi dengan layar sentuh dimaksudkan agar pengguna dapat secara langsung mengoperasikan alat-alat tanpa melalui media penghubung, misalnya melalui keyboard, mouse ataupun remote.

Penerapan atau penggunaaan media ICT berbasis proyektor interaktif dalam pembelajaran. Model Pembelajaran Interaktif berbasis ICT adalah model pembelajaran yang menggunakan teknologi dan melibatkan siswa secara langsung untuk berinteraksi dengan teknologi dalam berbagai jenis kegiatan pembelajaran dikelas menghitung, menggambar, mewarnai, mencocokan gambar, menggeser dan lain-lain sebagai media untuk mengembangkan aktivitas dan kemampuan berpikir anak (hands on and minds on) yang menghasilkan umpan balik atau feedback secara langsung. Model pembelajaran interaktif dalam penelitian ini dirancang agar siswa lebih termotivasi dalam proses pembelajaran.

\section{LCD proyektor}

LCD Proyektor digunakan untuk menampilkan output aplikasi dari Android Box ke sebuah permukaan datar seperti whiteboard dengan menggunakan kabel HDMI. LCD proyektor yang digunakan adalah LCD yang dapat menyorot dari arah samping, karena jika menyorot dari arah depan maka gambar akan tertutupi.

\section{Speaker Aktif}

Speaker Aktif digunakan untuk memperkuat dan memperjelas output suara dari Android Box, sehingga suara atau music dapat terdengar jelas oleh guru maupun siswa.

Selain komponen di atas, peneliti juga menyiapkan aplikasi pembelajaran untuk anak usia dini dengan memilih tiga tema, yaitu huruf hijaiyah, mengenal binatang dan mengenal pekerjaan. Tema: Mengenal Binatang. Materi binatang diajarkan dengan menggunakan aplikasi pembelajaran yang telah dibuat oleh tim peneliti, berikut adalah tampilan aplikasinya.
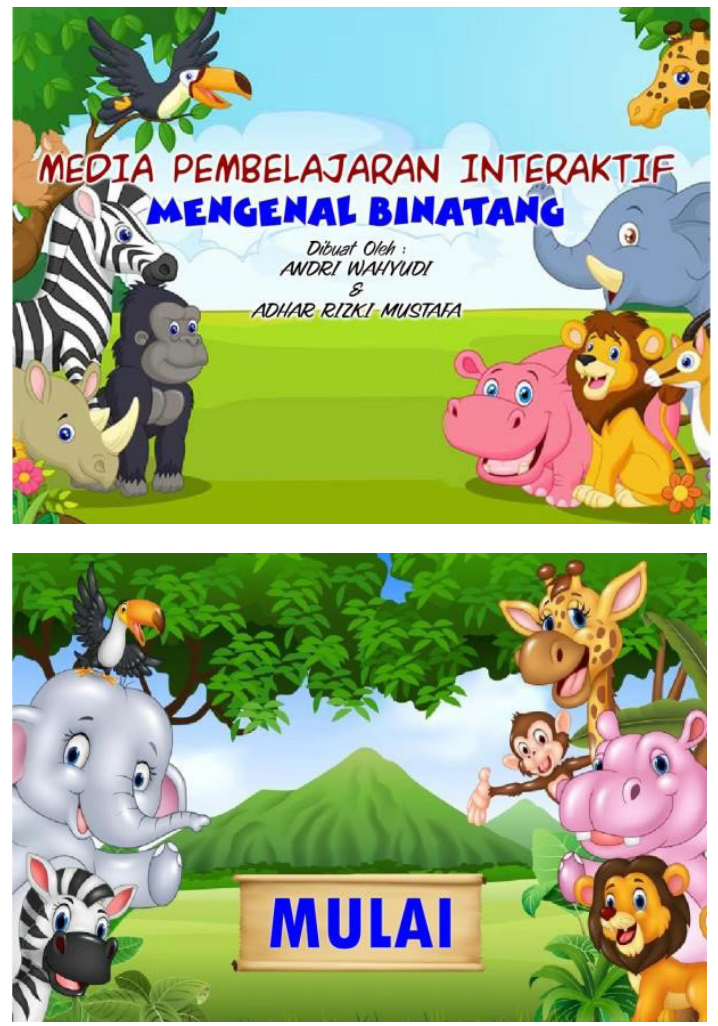

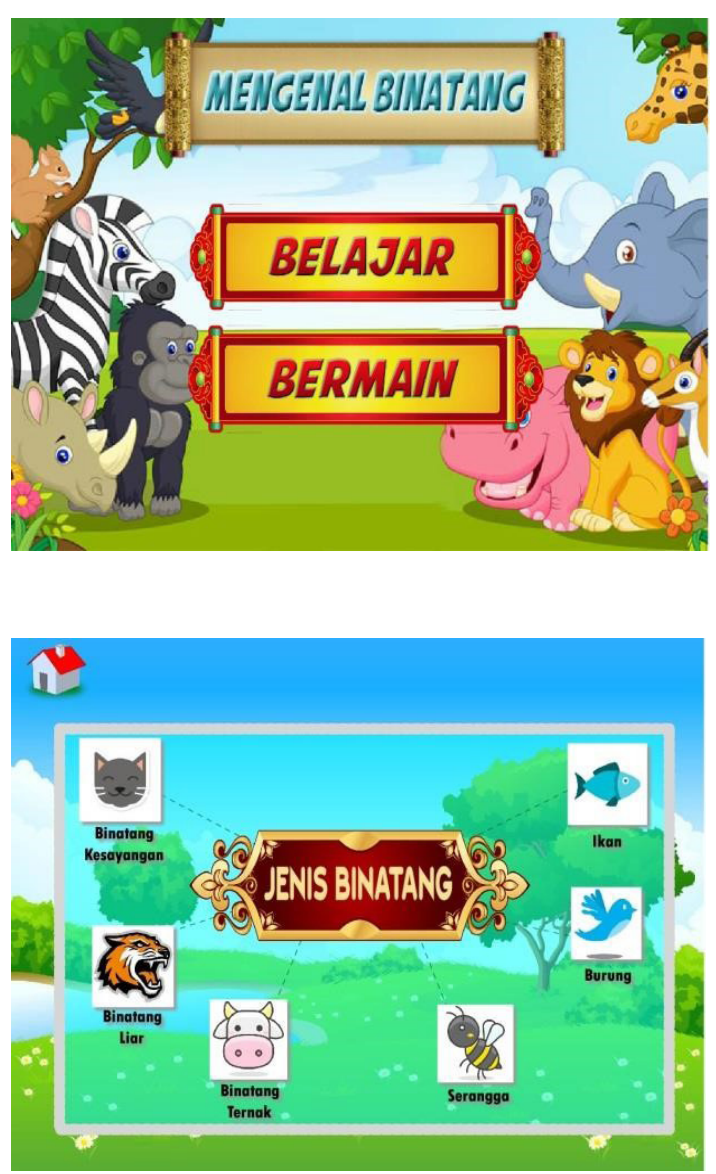

Tampilan gambar selanjutnya adalah macammacam binatang, ada binatang jenis serangga, ikan, burung, binatang kesayangan, binatang ternak dan binatang liar. Dalam aplikasi dapat dimainkan suara dari masingmasing binatang selain itu, suara dari namanama binatang bisa dikeluarkan dengan alasan bahwa anak-anak hanya mengenal gambar dan belum bisa membaca huruf atau tulisan.

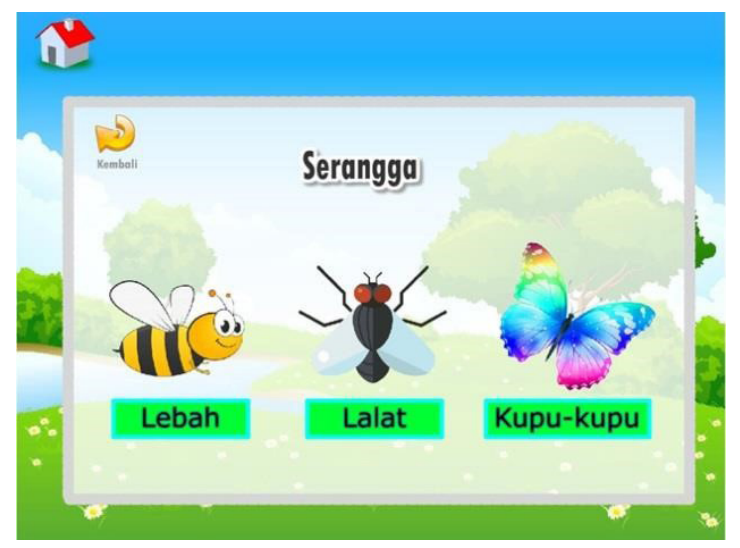

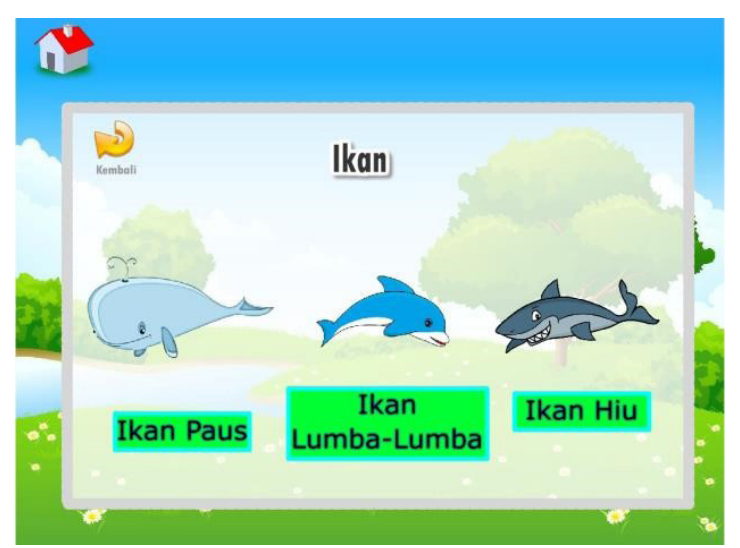
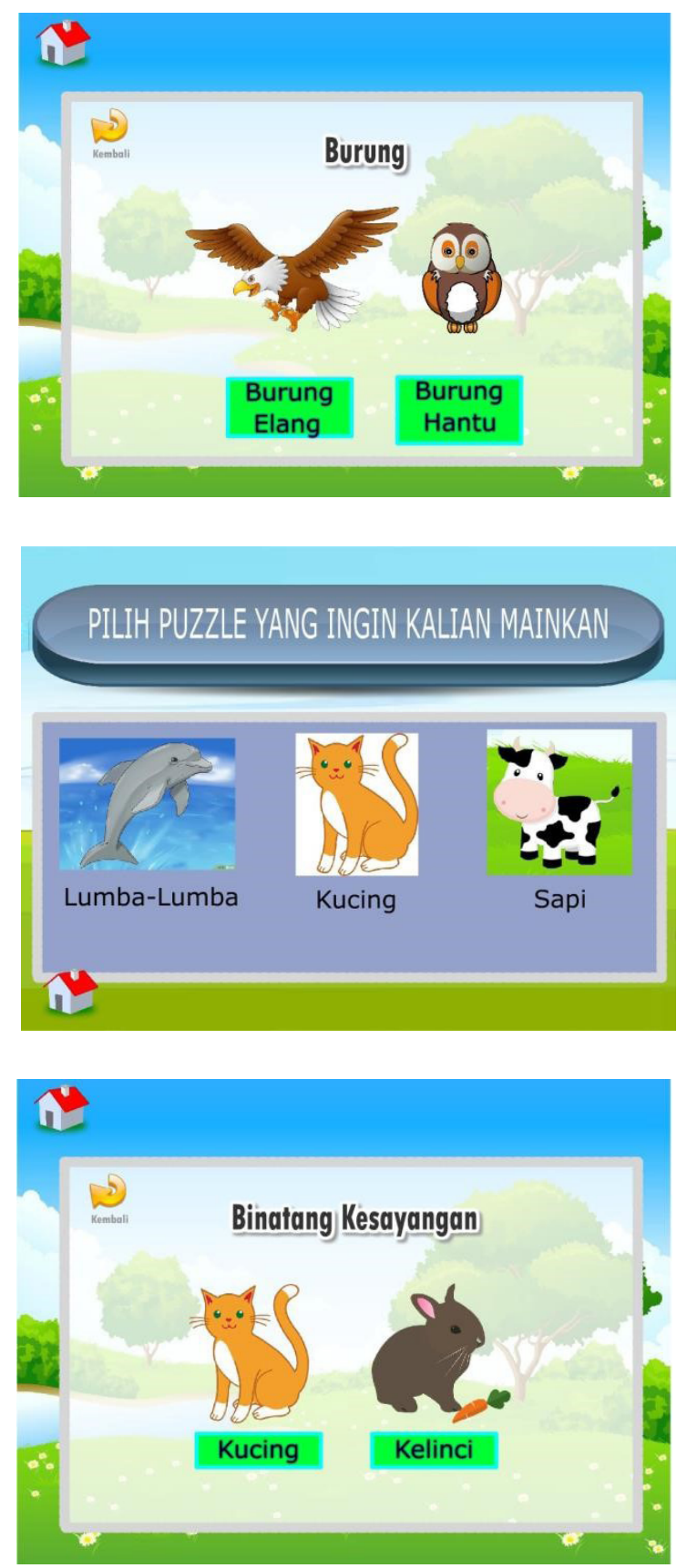


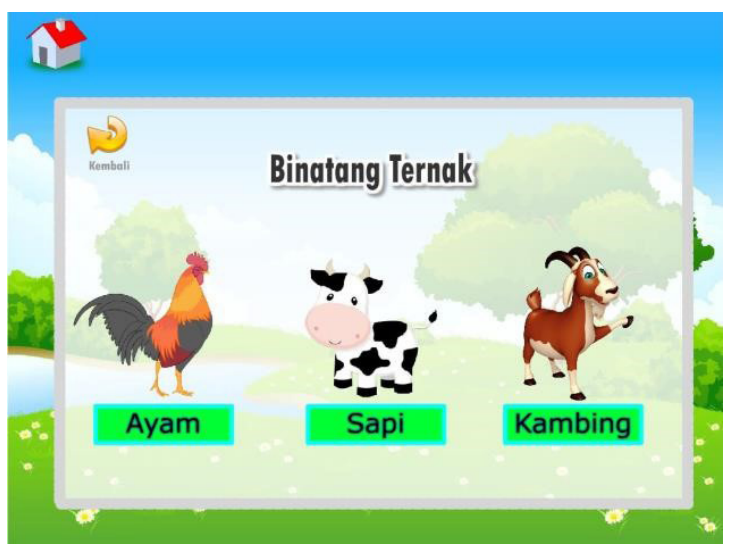

Setelah pengenalan binatang selesai, selanjutnya ditampilkan menu permainan. Siswa secara aktif dapat memindahkan potongan gambar ke kotak yang disediakan sehingga terbentuk gambar yang sempurna.
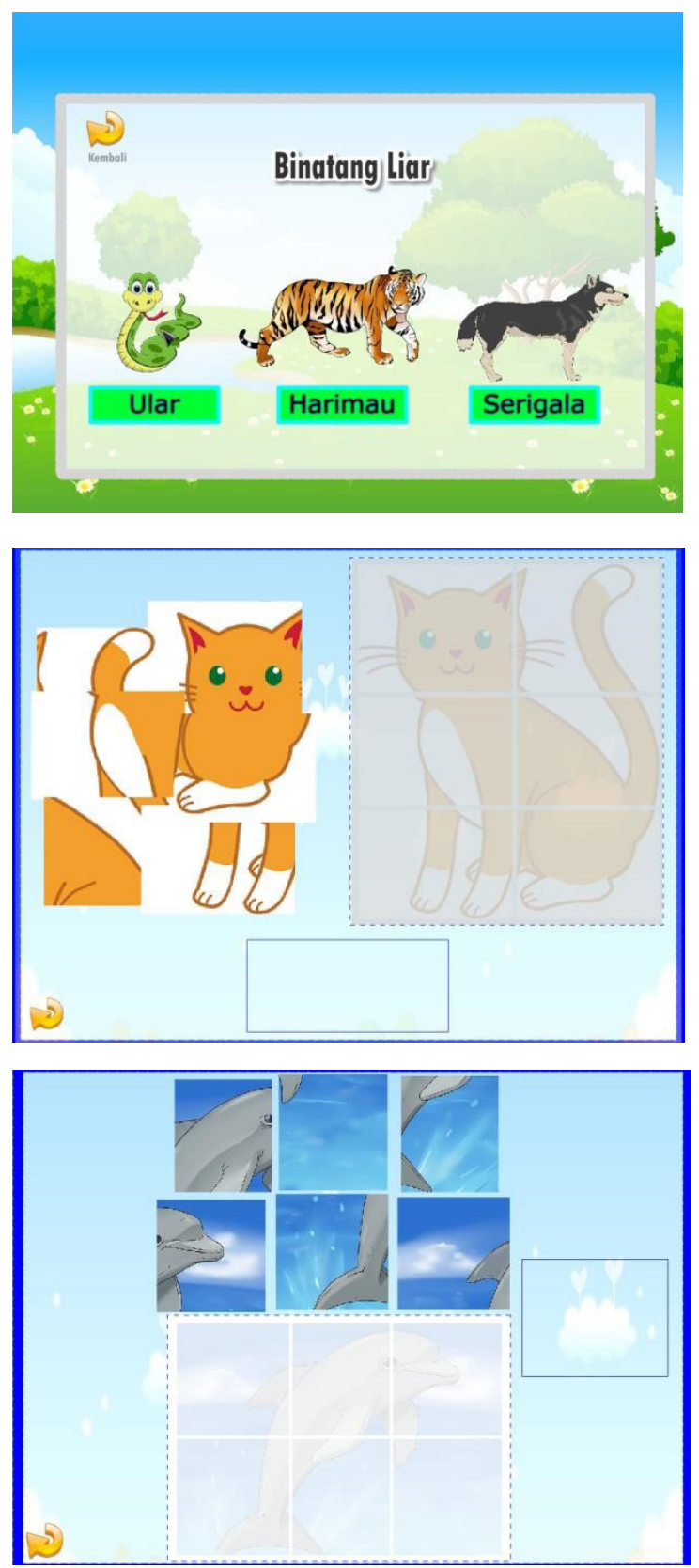
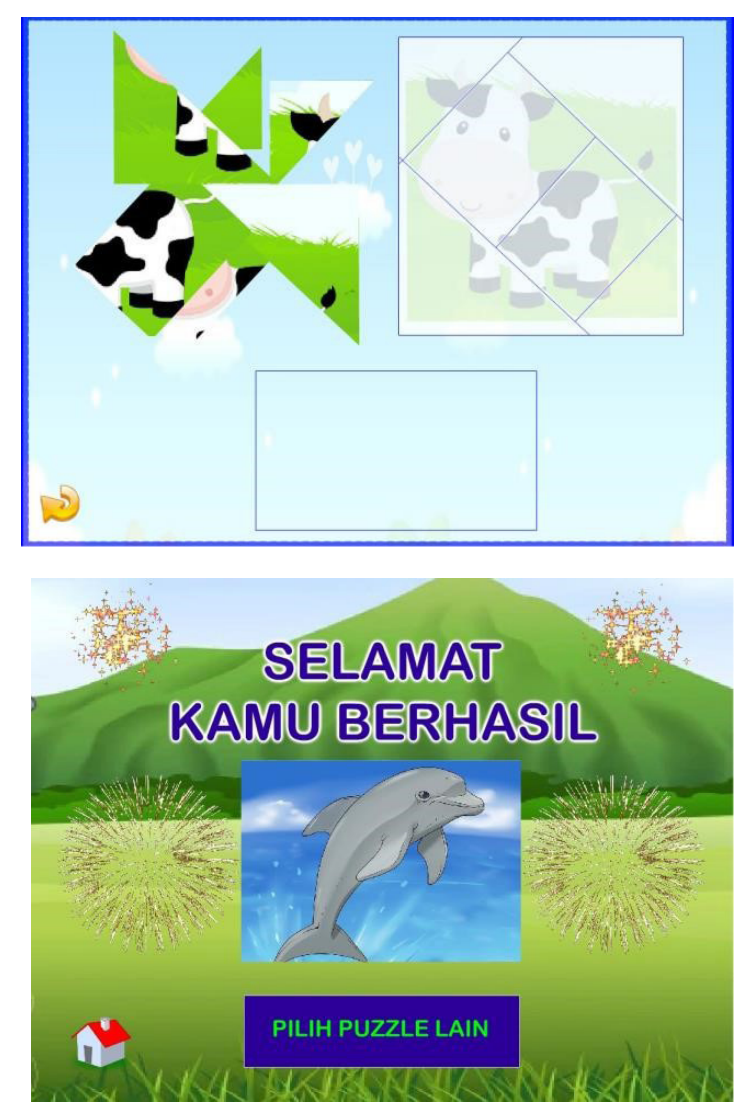

\section{Kegiatan Implementasi Media/Uji coba terbatas}

Langkah penelitian selanjutnya adalah implementasi pembelajaran di RA dengan menggunakan media ICT berbasis proyektor interaktif. Pemilihan sekolah dilakukan secara acak, dan terpilihlah RA Al-Hidayah yang berlokasi di kecamatan Cibaliung dan RA Al-Husaeni yang berlokasi di kecamatan Cikedal. Kedua kecamatan ini berada di lokasi dekat pantai dan berada jauh dari pusat pemerintahan kabupaten pandeglang. Peneliti berharap dengan pemilihan dua sekolah yang berada di daerah terluar di kabupaten pandeglang ini akan membantu para guru mengajar di kelas dengan menggunakan teknologi dan juga memberikan pengalaman dan suasana baru bagi para siswa yaitu belajar dengan menggunakan teknologi. Kegiatan implementasi ini bertujuan untuk mengetahui sejauh mana aktivitas belajar siswa RA yang pembelajarannya dengan menggunakan media ICT berbasis proyektor interaktif.

Acara implementasi diawali dengan sambutan dari kepala RA Al Hidayah, beliau 
sangat bahagia sekali karena RA nya terpilih sebagai tempat uji coba penggunaan teknologi yang dapat digunakan dalam membantu proses pembelajaran di kelas.

Selanjutnya salah seorang guru diminta untuk mengajar dengan menggunakan komputer. Siswa semua melihat ke layar monitor karena sangat terkesan dengan layar yang sangat besar seperti akan menonton Film, kata salah satu anak. Guru memulai pembelajaran seperti biasa, diawali dengan mengucapkan salam, memotivasi siswa, dan membaca doa / surat-surat pendek. Selanjutnya pembelajaran dengan menggunakan ICT, setelah guru menjelaskan materi dilanjutkan dengan permainan yang tersedia pada media. Pada mulanya siswa ragu-ragu dalam menjalankan permainan yang ada, namun karena dirasakan mudah, selanjutnya siswa berebut ingin mencoba permainannya.

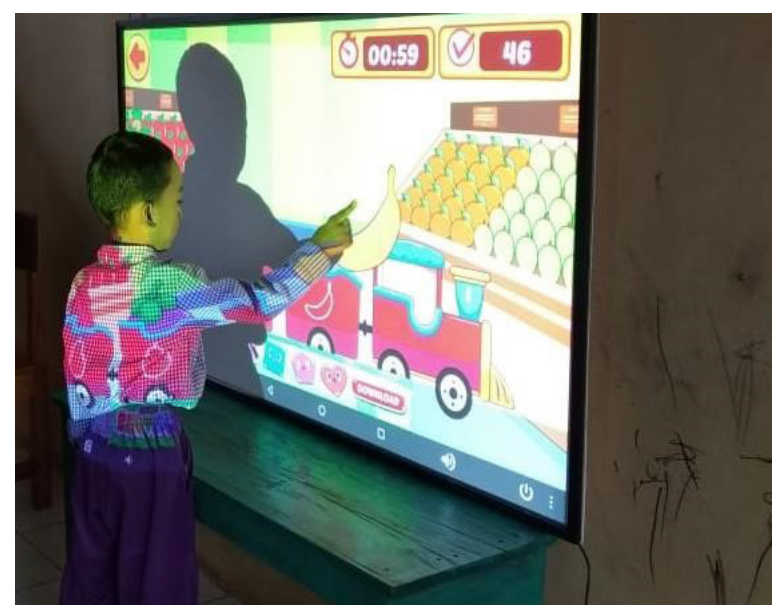

Gambar 2 Salah Satu Siswa Menggunakan Media ICT

Implementasi pembelajaran hari kedua dilaksanakan di RA Al Husaini, yang berada di kecamatan Cikedal Kabupaten Pandeglang. Hujan turun menemani tim dalam menempuh perjalanan ke RA Al Husaini, Lokasi sekolah yang berada di bukit sehingga peneliti harus berjalan menelusuri jalan merah agar bisa mencapai sekolah. Meskipun hujan besar mengguyur, anak-anak tetap semangat untuk belajar.

Sesaimpainya di sekolah, tim peneliti mempersiapkan media pembelajaran. Persiapan dilakukan cukup lama, karena banyak komponen yang harus terpasanng.
Setelah media pembelajaran siap digunakan, anak-anak diminta untuk masuk ke dalam kelas. Proses pembelajaran dengan menggunakan media ICT berbasis proyektor interaktif di bimbing oleh Kepala RA Al Husaeni yang telah mengikuti kegiatan pelatihan sebelumnya. Ibu guru Nampak masih terbatabata menggunakan media, sehingga dibantu oleh tim dalam mengoperasikannya. Guru menjelaskan materi dengan menggunkaan media ICT diselingi dengan cerita-cerita yang sesuai dengan kondisi lingkungan di kecamatan Cikedal.

Guru memilih materi dengan tema Binatang. Ketika guru bertanya "siapa yang pernah ke kebun binantang?" anak-anak menjawab dengan lantang "saya bu guru", selanjutnya guru bertanya "binatang apa yang kalian ketahui?", anak-anak menyebutkkan nama-nama binatang seperti yang tertera pada layar monitor. Tidak ada yang menarik ketika siswa menjawab nama-nama binatang. Selanjutnya guru menjelaskan binatang dengan menggunakan media ICT dengan salah satu menunya adalah suara binatang. Anak-anak menunjukkan ekspresi yang terkagum dan ketakutan ketika dibunyikan suara binatang harimau, ular, lebah, serigala, ikan lumba-lumba.

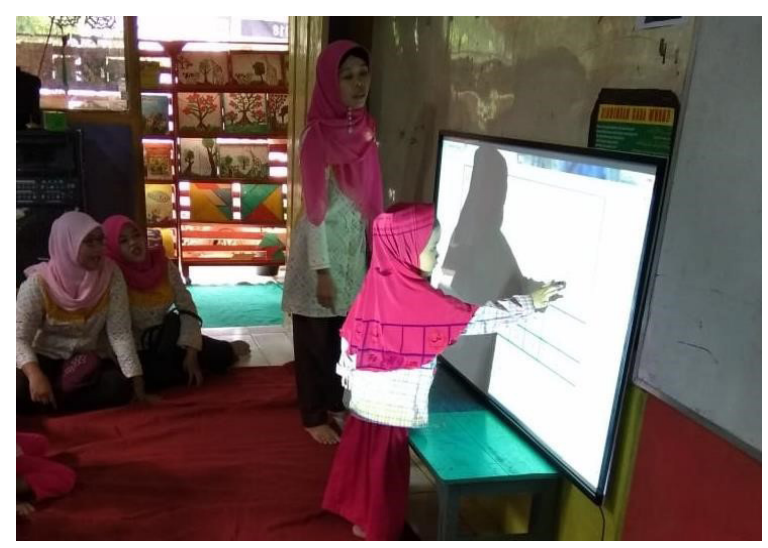

Gambar 5 . Salah Satu Siswa Menggunakan Media ICT

Setelah penjelasan materi selesai dilaksanakan, guru meminta anak-anak untuk maju ke depan mencoba permainan yang ada yaitu mencocokan antara nama binatang dengan gambar binatang.

Kepiawaian siswa dalam menggunakan media layar sentuh masih kaku, anak-anak terus secara bergantian menggunakan media 
tersebut. Bahkan ada beberapa siswa yang sudah pandai memainkannya.

\section{HASIL ANGKET}

Instrumen angket yang berkaitan dengan materi media ICT berbasis proyektor interaktif terdiri dari beberapa item pernyataan, antara lain mengenai aplikasiyang digunakan, cara penggunaan media, dan kesesuaian $\mathrm{m}$ e $\mathrm{d}$ i a dengan kurikulum pembelajaran di RA

Tabel 1 Prsentase Respon Peserta mengenai Penggunaan Media ICT berbasis Proyektor Interaktif

\begin{tabular}{|l|c|c|c|c|l|}
\hline \multicolumn{1}{|c|}{ Respon } & 1 & 2 & 3 & 4 & Rata2 \\
\hline Sangat Baik & 69.1 & 50.9 & 37 & 51.9 & 52.2 \\
\hline Baik & 29.1 & 45.5 & 53.7 & 46.3 & 43.6 \\
\hline Kurang Baik & 1.82 & 3.64 & 9.26 & 1.85 & 4.14 \\
\hline Jumlah & & & & & 100 \\
\hline
\end{tabular}

Keterangan

1: animasi media

2. kesesuaian gambar/video

3. penggunaan media

4. kesesuaian aplikasi dengan kurikulum

Pada table 1 nampak bahwa guru memberikan resoon yang positif terhadap penyusunan aplikasi media pembelajaran untuk anak usia dinidan juga respon positif terhadap pemanfaatan media ICT berbasis proyektor interaktif dalam pembelajaran RA. Pertanyaan selanjutnya, untuk mengetahui ketersediaan sarana dan prasarana yang ada di sekolah, peneliti memberikan pertanyaan: Apakah ada media ICT di sekolah Bapak/Ibu mengajar?, jawaban atau respon dari peserta menunjukkan bahwa sebesar $85,71 \%$ sekolah tidak memiliki media ICT, 5,3\% memiliki ICT dan $8.93 \%$ tidak mengisi angket. Kondisi yang memprihatinkan, di jaman modern, pendidikan belum mampu memanfaatkan ICT dalam proses pembelajaran. Pertanyaan selanjutnya: apakah Bapak/lbu menginginkan sekolah tersebut dilengkapi dengan media ICT?, kalau dilihat dari harapan para guru dalam penyediaan media ICT di sekolah sangat tinggi, yaitu sebanyak $87.5 \%$ guru mengharapkan adanya bantuan dari pihak mana saja untuk penyediaan barang khususnya media ICT dalam membantu pembelajaran di RA sehingga menjadi lebih menarik dan menyenangkan. Sedangkan sebanyak $12.5 \%$ guru tidak memberikan respon terhadap pertanyaan.

\section{KESIMPULAN}

Kesimpulan dalam penelitian ini antara lain:

1. tersusun aplikasi pembelajaran interaktif bagi anak usia dini yang menggunakan media ICT berbasis proyektor interaktif,

2. Proses pembelajaran tematik di RA yangmenggunakan media media ICT berbasis proyektor interaktif sangat menyenangkan, hal ini ditunjukkan oleh antusias siswa dalam mengikuti pelajaran, dan juga terjadi peningkatan aktifitas belajar siswa RA di Kabupaten Pandeglang.

3. Guru memberikan respon yang positif terhadap penggunaan proyektor interaktif dalam pembelajaran tematik di kelas RA

\section{DAFTAR PUSTAKA}

Borg and Hall (1983). Educational Research, An Introduction. New York and London. Longman Inc.

Crescenzi, J., \& Price (2014) The role of touch inpreschool children's learning. Australian Journal of Language and Literacy, 37(2).Pp 86-96

Aisyi, Fauziyah Kariem; Siscka Elvyanti, TjetjeGunawan, Elih Mulyana. (2013) Jurnallnnovation of Vocational Technology Education: Pengembangan Bahan Ajar TIK SMP Mengacu pada PembelajaranBerbasis Proyek.9(2). pp. 117-128

Gang Liu, Xiaocheng Zhou, (2017) The application and value of virtual animation in Jinzhai revolutionary site, 3rd International Conference on Energy Materials and Environment Engineering. IOP Publishing IOP Conf. Series: Earth and Environmental Science.

Gertner , R. A., (2011) The Effect of Multimedia Tecnology on Learning. Thesis : The Faculty of the Graduate School Abilene Christian University Glasersfeld (1982) n Interpretation 
of Piaget's Constructivism, http:// creativecommons.org/licenses/by$\mathrm{ncnd} / 2.0 /$. Pre-print version of $25 \mathrm{Feb}$ 2006

Hayumuti; Susilo, H.; Manahal, S., (2016) Penggunaan Multimedia CD Interaktif dalam Peningkatan Aktivitas dan Hasil Belajar IPA Tema Selalu Berhemat Energi di Kelas IV SDN Klanderan Kediri. Jurnal Pendidikan: Teori, penelitian dan Pengembangan volume 1 (7). Hal: 14371441

Hwang, G.-J., Wu, C.-H., \& Kuo, F.-R. (2012). Effects of Touch Technology-based Concept Mapping on Students' Learning Attitudes and Perceptions. Educational Technology \& Society, 16 (3), pp. 274285.

Ibrahim, Ali (2011). Pengembangan Sistem Informasi Monitoring Tugas Akhir Berbasis Short Message Service (SMS) Gateway di Fasilkom Unsri. Jurnal JUSI,1(2)pp. 81-92
Mustika, Eka (2013) Pembelajaran Sain Berbasis ICT untuk Meningkatkan ICT Literacy Siswa Sekolah Dasar. Jurnal PEDAGOGIK 1(2) pp. 30-40

Rosa, J.P, (2016) Experiences, perceptions and attitudes on ICT integration: $A$ case study among novice and experienced language teachers in the Philipines. International Journal of Education and Development using Information and Communication Technology (IJEDICT), vol 12(3) pp. 37-57

Siahaan, Sardianto Markos (2012) Penggunaan Teknologi Informasi dan Komunikasi dalam Pembelajaran Fisika. Prosiding Seminar Nasional Fisika Universitas Sriwijaya, (Energi, Lingkungan, dan Teknologi Masa Depan: Tantangan dan Peluang Ilmu Fisika). pp. 13-20.

Suryadi, A., (2011) Pemanfaatan ICT dalam Pembelajaran. Jurnal Pendidikan Terbuka dan Jarak Jauh, Vol 8(1) Maret 2007: 83-98- 